\title{
Quality and yield of wheat crop as affected by different zinc application methods and levels
}

Laiq Zada ${ }^{1 *}$, Mohammad Jamal Khan ${ }^{1}$, Ishaq Mian Ahmad ${ }^{1}$, Rafiullah ${ }^{1}$, Hafeez Ur Rahim ${ }^{1}$, Murad Ali ${ }^{2}$, Samiullah ${ }^{3}$, Sajjad Ahmad ${ }^{4}$, Zaid Khan ${ }^{4}$ and Naseem Khan ${ }^{1}$

1. Department of Soil and Environmental Sciences, The University of Agriculture Peshawar-Pakistan

2. Cereal Crop Research Institute Pirsabak Nowshehra-Pakistan

3. Department of Horticulture, The University of Agriculture Peshawar-Pakistan

4. Department of Agronomy, The University of Agriculture Peshawar-Pakistan

*Corresponding author's email: zadalaiq259@gmail.com

Citation

Laiq Zada, Mohammad Jamal Khan, Ishaq Mian Ahmad, Rafiullah, Hafeez Ur Rahim, Murad Ali, Samiullah, Sajjad Ahmad, Zaid Khan and Naseem Khan. Quality and yield of wheat crop as affected by different zinc application methods and levels. Pure and Applied Biology. Vol. 6, Issue 3, pp814-820. http://dx.doi.org/10.19045/bspab.2017.60086

Received: 24/02/2017 Revised: $16 / 06 / 2017$ Accepted: 26/06/2017

Online First: 30/06/2017

\section{Abstract}

A field trail was performed at new developmental farm, The University of Agriculture Peshawar during winter 2012 to assess quality and yield of wheat crop as affected by different zinc application methods i.e foliar, soil and priming with $\mathrm{Zn}$. In priming wheat (serin-2010) seeds were soaked in 1 and $5 \% \mathrm{Zn}$ solution for 16 hours prepared from $\mathrm{ZnSO}_{4}$. In case of foliar application 2.5 and $5 \mathrm{~kg} \mathrm{ha}^{-1}$ of $\mathrm{ZnSO}_{4} .7 \mathrm{H}_{2} \mathrm{O}$ were used whereas in case of soil application, 5 and $10 \mathrm{~kg} \mathrm{ha}^{-1}$ of $\mathrm{Zn}$ as $\mathrm{ZnSO}_{4} 7 \mathrm{H}_{2} \mathrm{O}$ was surface applied before sowing wheat crop. The $\mathrm{NP}$ and $\mathrm{K}$ were also used as a basal dose @ of 120:90:60 kg ha-1 respectively. The result showed that biological yield, grain yield, soil extractable $\mathrm{Zn}$, uptake of phosphorous and $\mathrm{Zn}$ were significantly enhanced when Zn was applied as foliar spray @ of $2.5 \mathrm{~kg} \mathrm{ha}^{-1}$ followed by $5 \mathrm{~kg} \mathrm{ha}^{-}$ ${ }^{1}$ as compared to soil application and control treatments. Similarly, foliar application of Zn @ of $2.5 \mathrm{~kg} \mathrm{ha}^{-1}$ resulted in maximum, biological yield (7516.7 kg ha-1), grain yield (4490 kg ha-1), soil extractable $\mathrm{Zn}\left(1.003 \mathrm{mg} \mathrm{kg}^{-1}\right)$, phosphorous in leaf tissue $\left(451.36 \mathrm{mg} \mathrm{kg}^{-1}\right)$ and $\mathrm{Zn}$ in leaf tissue ( T6= $46.63 \mathrm{mg} \mathrm{kg}^{-1}$ ) followed by Zn application @ of $5 \mathrm{~kg} \mathrm{ha}^{-1}$.Soil application and control treatments resulted minimum biological yield, grain yield, soil extractable Zn, uptake of phosphorous and $\mathrm{Zn}$. From these results it was concluded that quality and yield of wheat crop were significantly enhanced when zinc was applied as a foliar spray @ of $2.5 \mathrm{~kg} \mathrm{ha}^{-1}$ as compared to other methods. Foliar spray at @ of $2.5 \mathrm{~kg} \mathrm{ha}^{-1}$ is recommended in zinc deficient soils to get better quality and yield of wheat crop.

Keywords: Wheat; $\mathrm{ZnSO}_{4} .7 \mathrm{H}_{2} \mathrm{O}$; Biological yield; Grain yield

\section{Introduction}

Wheat (Triticum aestivum L.) is the most important crop among cereal belongs to family Poaceae and is considered as a staple food of Pakistan and at world level. It is also one of the major sources of protein and 
carbohydrates both for human beings and animals. It is grown in Pakistan on an area of 9062 thousand hectares.23.4 million tons is its total production with a $2585 \mathrm{~kg} \mathrm{ha}^{-1}$ average yield [1]. Due to unsuitable row spacing and seed rate its yield is low in Pakistan. These two factors are the most important management factors which are affecting wheat agronomic characteristics [2-4]. In Khyber Pakhtunkhwa, its average yield is $1565 \mathrm{~kg} \mathrm{ha}^{-1}$ and is sown on area of 769.5 hectare with a total production of 1204.5 tons [5]. Zinc is one of the crucial and important elements which are needed in small amount for the growth of plant. Plant absorbs it in divalent form $\left(\mathrm{Zn}^{2+}\right)$. Various metabolic functions such as Hydrogenase, auxin metabolism, cytochrome Synthesis, and the ribosomal fraction stabilization are stimulated by this element (Tisdale et al., [6]. Plant life processes that is photosynthesis, Synthesis of chlorophyll, metabolism of nitrogen and its uptake is affected greatly by this element. Its deficiency reduces contents of proteins and its synthesis [7].

Zinc deficiency exhibits, necrosis, poor growth and interveinal chlorosis of lower leaves. Due to its deficiency reddish or brownish spot often occurs on the lower leaves which reduce the seed production [8]. Its deficiency is also common where wheat is grown on calcareous soils. As a result of this a large population of the world lacks its adequate nutrition Maqsood et al. [9]. A national survey revealed that in Pakistan its deficiency in $37 \%$ of children's and $41 \%$ in mothers [10]. Foliar application on wheat crop with different micronutrients is better than the application of soil and it is effectively used to overcome the deficiency in subsoil $[11,12]$.

Objectives of this study is to:
Assess the effect of $\mathrm{Zn}$ on wheat yield and its uptake under alkaline calcareous soil.

To evaluate different application methods viz soil, foliar and soaking of seeds in $\mathrm{Zn}$ solution under the given soil and climatic condition.

To investigate proper doses of $\mathrm{Zn}$ for the given application methods

\section{Methods and materials}

The experiment was conducted at new developmental farm of Khyber Pakhtunkhwa University of agriculture Peshawar, during winter 2012.Before the start of trail a composite soil sample was taken from the experimental site and analyzed for various physico-chemical characteristic besides the concentration of $\mathrm{Zn}$ and phosphorous which were $0.896 \mathrm{mg} \mathrm{kg}^{-1}$ and $10.38 \mathrm{mg} \mathrm{kg}^{-1}$ in composite soil sample. Three $\mathrm{Zn}$ application methods including seed priming, foliar and soil were used in the experiment. In the seed priming techniques, seeds were soaked in the desired $\mathrm{Zn}$ solution ( 1 or $5 \%$ solution) for 16 hours and then dried back to original moisture level through sun drying. In foliar spray $\left(2.5 \mathrm{Kg} \mathrm{ha}^{-1}\right.$ and $5 \mathrm{Kg} \mathrm{ha}^{-1}$ of $\mathrm{ZnSO}_{4} .7 \mathrm{H}_{2} \mathrm{O}$ ), the plots were first sprayed just with water to know the amount of solution to be needed to cover the entire plot. After knowing the amount of water, the required concentrations were prepared and sprayed in morning. In case of soil application, the required amount $(5$ and $10 \mathrm{~kg}$ $\mathrm{ha}^{-1}$ of $\mathrm{ZnSO}_{4}$ ) was mixed with soil and then uniformly broadcasted in the treatment plots allocated to soil application. Plot size was $4 \mathrm{~m}$ $\mathrm{x} 3 \mathrm{~m}$. Sowing was done on flat beds in rows spaced $30 \mathrm{~cm}$. First irrigation was given few days after sowing while the subsequent irrigation was adjusted according to the need of the crop and avoiding the over irrigation strictly. All the other agronomic practices were kept normal and uniform for all the treatments. The basal dose of fertilizer i.e. half of $\mathrm{N}$ and full dose of $\mathrm{P}$ and $\mathrm{K}(60,90$ and $60 \mathrm{~kg}$ respectively) were applied at the 
time of sowing while remaining half of $\mathrm{N}$ was applied at knee high stage.

Data was recorded on the following parameters:

\section{AB-DTPA extractable $\mathbf{Z n}$}

$\mathrm{Zn}$ (a micronutrient) was extracted in ABDTPA solution as explained by Soltanpur and Schawab [13]. Zn concentration was calculated by atomic absorption spectrophotometer (perkin elmer 2138) using cathode lamp of respective element and acetylene gas. The machine was calibrated with standard of the respective element before analysis of said element in AB-DTPA soil solution (Table 1).

Table 1. Methods of zinc application and its rates

\begin{tabular}{|l|c|c|}
\hline Treatments & Methods & Zn levels \\
\hline T1 & Control (dry seeds) & 0 \\
\hline T2 & Control (water soaked) & 0 \\
\hline T3 & Control (water spray) & 0 \\
\hline T4 & Seeds priming with Zn & $1 \%$ \\
\hline T5 & Seeds priming with Zn & $5 \%$ \\
\hline T6 & Foliar Zn & $2.5 \mathrm{Kg} \mathrm{ha}^{-1}$ \\
\hline T7 & Foliar Zn & $5 \mathrm{Kg} \mathrm{ha}^{-1}$ \\
\hline T8 & Soil Zn & $5 \mathrm{~kg} \mathrm{ha}^{-1}$ \\
\hline T9 & Soil Zn & $10 \mathrm{~kg} \mathrm{ha}^{-1}$ \\
\hline
\end{tabular}

\section{Zn concentration in leaf tissue}

$0.5 \mathrm{~g}$ oven dry and fully ground leaf sample was taken into $150 \mathrm{ml}$ conical flask and added to it $15 \mathrm{ml}$ of concentrated hydrochloric acid (HCL) and left over night. $5 \mathrm{ml}$ of $\mathrm{HCLO}_{4}$ (per chloric acid) along with two $\mathrm{ml}$ of concentrated sulphuric acid $\left(\mathrm{H}_{2} \mathrm{SO}_{4}\right)$ were added to it. Heated it till it was digested, which was proved due to its fumes layering in the given beaker. Heat was given continuously till the disappearance of fume and the liquid became clear. The liquid was cooled and added to it about fifty $\mathrm{ml}$ of distill water and filtered it with Watman filter paper-42. The filtrate was collected in $100 \mathrm{ml}$ volumetric flask and made its volume with distil water [14]. $\mathrm{Zn}$ was determined after wet digestion by atomic absorption spectrophotometer (perkin Elmer 2138) using cathode lamp of respective element and acetylene gas. The machine was calibrated with standard of the respective element before analysis of said element in AB-DTPA soil solution.
Phosphorous concentration in leaf tissue

0.5 g oven dry and fully ground leaf sample was taken into $150 \mathrm{ml}$ conical flask and added to it $15 \mathrm{ml}$ of concentered hydro chloric acid (HCL) and left over night. $5 \mathrm{ml}$ of $\mathrm{HCLO}_{4}$ (per chloric acid) along with two $\mathrm{ml}$ of concentrated sulphuric acid $\left(\mathrm{H}_{2} \mathrm{SO} 4\right)$ were added to it. Heated it till it digested which is proved due to its fumes layering in the given beaker. Heat was given continuously till the disappearance of fume and the liquid became clear. The liquid was cooled and added to it about fifty $\mathrm{ml}$ of distill water and filtered it with Watman filter paper-42. The filtrate was collected in $100 \mathrm{ml}$ volumetric flask and made its volume with distil water [14]. To measure phosphorous $1 \mathrm{ml}$ sample was taken in 25 $\mathrm{ml}$ of volumetric flask and added to it four $\mathrm{ml}$ ascorbic acid mix reagent and diluted it up to the mark. Reading was taken when bluish color was produced.

Biological yield ( $\left.\mathrm{kg} \mathrm{ha}^{-1}\right)$

Biological yield was determined by harvesting two central rows in each sub plot 
and then sun dried, weighed and changes into $\mathrm{kg} \mathrm{ha}^{-1}$ by formula.

Biological yield $(\mathrm{kg} / \mathrm{ha})=$ Dry weight mass $(\mathrm{Kg}) \times 10000$

Grain yield $\left(\mathrm{kg} \mathrm{ha}^{-1}\right)$ (No of rows)(RxR distance)(Row length)

By threshing the dried harvested materials of biological yield grain yield was determined. To note the grain yield in each treatment the seeds were cleaned after threshing and after that it is changed $\left(\mathrm{kg} \mathrm{ha}^{-1}\right)$ by using the given formula as under

Grain yield $(\mathrm{kg} / \mathrm{ha})=$ Grain yield $(\mathrm{Kg}) \times 10000$

(No of rows)(RxR distance)(Row length)

\section{Results and discussion}

The result obtained on soil extractable $\mathrm{Zn}$ is given in Table 2. The result showed that there were significant variations among the means of all treatments. The extractable $\mathrm{Zn}$ content ranged from 0.613 to $1.003 \mathrm{mg} \mathrm{kg}^{-1}$. Maximum value of soil extractable $\mathrm{Zn}$ was recorded in T6 (1.003) followed by T7 (0.94) and T9 (0.87) respectively. Similarly, minimum value of soil extractable $\mathrm{Zn}$ was recorded in T2 (0.613). Zn was deficient throughout all treatments as indicated in the Table 2. The deficiency of $\mathrm{Zn}$ might be due to high level of phosphorus or soil $\mathrm{pH}$ and hence its uptake was reduced. Thus our result were somehow in line with those of Salimpour et al. [15], Khorgamy and Farnis, [16], Das et al. [17], Marschner et al. [18], Sharma et al. [19] they observed similar result that accumulation of phosphorus in excess amount cause $\mathrm{Zn}$ deficiency. Similarly the result obtained on $\mathrm{Zn}$ in wheat leaves are given in Table 2 .The result showed that there were significant variations when different treatments were applied. $\mathrm{Zn}$ in wheat leaves ranged from 30.96 to 46.6. Maximum Zn uptake was recorded in (T6) which was 46.63 followed by T7, T4 and T5 (respectively. Similarly minimum $\mathrm{Zn}$ uptake was recorded in (T1) which was 30.96. Data on $\mathrm{Zn}$ uptake clearly indicated that as the concentration of phosphorous increased in the soil, uptake of plant $\mathrm{Zn}$ decreased. It showed an antagonistic interaction between
$\mathrm{Zn}$ and phosphorous. . Webb and Loneagan, [20], Marschner et al. [18], Hu et al. [21] and Bukvicl et al. [22] observed similar result that uptake of phosphorous, its concentration and transportation increased in shoot and leaves due to the absence or low concentration of $\mathrm{Zn}$ which in plant lead to accumulation of toxin. Higher phosphorous concentration will lead only with $\mathrm{Zn}$ deficiency and not with micronutrient deficiencies. Similarly minimum uptake of $\mathrm{Zn}$ by wheat crop might also be due low level of organic matter or high level of lime contents in the soil. Katyal and Randhawa [23] observed similar result that simple organic compounds like hydroxy acids, phosphoric acids and also amino acids increase the mobility and solubility of $\mathrm{Zn}$ in soils while making complexes with $\mathrm{Zn}$. Zn availability will increase with the increase of soil organic matter contents. Too high contents of organic matter in soils like peat and muck cause $\mathrm{Zn}$ deficiency due to the $\mathrm{Zn}$ binding on the solid state of humic substances. Shukla and Moris in [24] and [25] also observed similar result that in limed soils $\mathrm{Zn}$ movement was lower than acidic soils and thus the crop absorbed little amount of $\mathrm{Zn}$. Zn uptake and its deficiency were due to the high amount of lime contents.

The result of phosphorous in wheat leaves showed that there were significant variations when different treatments were applied (Table 2). Phosphorus ranged from 233 to $451.36 \mathrm{mg} \mathrm{kg} \mathrm{kg}^{-1}$.Maximum phosphorus uptake was recorded in (T6) which was 451.36 followed by T8 and T7 respectively. Similarly minimum value of phosphorous was recorded in (T5) which was 233 (Table 2). Data on phosphorous uptake clearly indicated that as the $\mathrm{Zn}$ concentration decreased in the soil phosphorous uptake in plant increased. It means that there was antagonistic interaction between $\mathrm{Zn}$ and phosphorous. Webb and Loneagan, [20], 
Marschner et al. [18], Hu et al. [21] and Bukvicl et al. [22] observed similar result that phosphorous uptake, its concentration and transportation increases in shoot and leaves due to the absence or low concentration of $\mathrm{Zn}$ which in plant lead to accumulation of toxin. Higher phosphorous concentration will lead only with $\mathrm{Zn}$ deficiency and not with micronutrient deficiencies. It means that as compared to phosphorous, permeability of cell membrane in root increased due to the increase of $\mathrm{Zn}$ deficiency.

The result of biological yield showed that there were significant variations when different treatments were applied (Table 2). Biological yield ranged from 2662.3 to $7516.7 \mathrm{~kg} \mathrm{ha}^{-1}$. Minimum value of biological yield was recorded in ( $\left.\mathrm{T}_{1}\right)$ control) which was $2662.3 \mathrm{~kg} \mathrm{ha}^{-1}$, while the maximum biological yield was recorded in $\mathrm{T}_{6} 7516.7$ $\mathrm{kg} \mathrm{ha}^{-1}\left(\mathrm{Zn}\right.$ foliar application) followed by $\mathrm{T}_{7}$ $\left(6746 \mathrm{~kg} \mathrm{ha}^{-1}\right)$ as shown in Table 2. Rajput et al. [26] also observed similar result that biological yield was increased with the foliar application of $\mathrm{Zn}, \mathrm{N}$ and $\mathrm{K}$. The superiority of $\mathrm{Zn}$ application as a foliar spray over other treatments may due to its full and efficient utilization whereas soil application may encounter soil fixation.

The result of grain yield showed that there were significant variations among the means of different treatments. It ranged from 1662.3 to $2512.7 \mathrm{~kg} \mathrm{ha}^{-1}$. Grain yield showed significant increase when $\mathrm{Zn}$ was applied as foliar spray. The maximum grain yield was recorded in $\mathrm{T}_{6}\left(2512.7 \mathrm{ha}^{-1}\right)$ and $\mathrm{T}_{7}(6175 \mathrm{~kg}$ $\left.\mathrm{ha}^{-1}\right)$ followed by $\mathrm{T}_{5}\left(2321.7 \mathrm{~kg} \mathrm{ha}^{-1}\right)$ and $\mathrm{T}_{4}$ $\left(5677.5 \mathrm{~kg} \mathrm{ha}^{-1}\right)$, while minimum grain yield (1662.3 $\left.\mathrm{kg} \mathrm{ha}^{-1}\right)$ was recorded in $\mathrm{T}_{1}$ (control) and $\mathrm{T}_{2}\left(1700 \mathrm{~kg} \mathrm{ha}^{-1}\right)$ as shown in Table 2. Tourn et al. [27], Zorita et al. [28] and Grewal et al. [29] also observed similar result and found higher grain yield with $\mathrm{Zn}$ foliar application.

Table 2. ABDTPA extractable zinc, Zinc (Zn) and Phosphorous (P) in leaf tissues, biological yield (B.Y) and grain yield (G.Y) as affected by different zinc application methods in wheat crop

\begin{tabular}{|l|c|c|c|c|c|}
\hline Treatments & $\begin{array}{l}\text { ABDTPA Ext } \\
\mathbf{Z n}\left(\mathbf{m g ~ K g} \mathbf{~}^{-1}\right)\end{array}$ & $\begin{array}{l}\text { Zn in leaf } \\
\text { tissues }\left(\mathbf{m g ~ K g} \mathbf{~ g}^{-1}\right)\end{array}$ & $\begin{array}{l}\text { P in leaf } \\
\text { Tissues }\left(\mathbf{m g ~ K g}^{-1}\right)\end{array}$ & $\begin{array}{l}\text { B.Y } \\
\left(\mathbf{K g ~ h a}^{-1}\right)\end{array}$ & $\begin{array}{l}\mathbf{G . Y} \\
\left(\mathbf{K g ~ h a}^{-1}\right)\end{array}$ \\
\hline $\mathrm{T}_{1}$ & $0.713 \mathrm{cde}$ & $30.96 \mathrm{~d}$ & $299.10 \mathrm{bcd}$ & $2662.3 \mathrm{f}$ & $1730 \mathrm{f}$ \\
\hline $\mathrm{T}_{2}$ & $0.613 \mathrm{e}$ & $31.58 \mathrm{~cd}$ & $279.87 \mathrm{cde}$ & $2700 \mathrm{f}$ & $1786.7 \mathrm{f}$ \\
\hline $\mathrm{T}_{3}$ & $0.75 \mathrm{cde}$ & $32.03 \mathrm{~cd}$ & $298.61 \mathrm{bcd}$ & $2763.3 \mathrm{f}$ & $1836.7 \mathrm{f}$ \\
\hline $\mathrm{T}_{4}$ & $0.80 \mathrm{bcd}$ & $39.3 \mathrm{~b}$ & $259 \mathrm{de}$ & $4216.7 \mathrm{e}$ & $3678.3 \mathrm{e}$ \\
\hline $\mathrm{T} 5$ & $0.64 \mathrm{de}$ & $38.31 \mathrm{~b}$ & $233 \mathrm{e}$ & $4321.7 \mathrm{e}$ & $3833.3 \mathrm{de}$ \\
\hline $\mathrm{T}_{6}$ & $1.003 \mathrm{a}$ & $46.63 \mathrm{a}$ & $451.36 \mathrm{a}$ & $7516.7 \mathrm{a}$ & $4490 \mathrm{a}$ \\
\hline $\mathrm{T}_{7}$ & $0.94 \mathrm{ab}$ & $41.5 \mathrm{ab}$ & $387.80 \mathrm{bc}$ & $6746 \mathrm{~b}$ & $4158.3 \mathrm{~b}$ \\
\hline $\mathrm{T} 8$ & $0.71 \mathrm{cde}$ & $36.3 \mathrm{bcd}$ & 347.88 & $6200 \mathrm{c}$ & $4023.7 \mathrm{bc}$ \\
\hline $\mathrm{T}_{9}$ & $0.87 \mathrm{abc}$ & $36.75 \mathrm{bc}$ & $261.30 \mathrm{de}$ & $5893.3 \mathrm{c}$ & $3943.3 \mathrm{~cd}$ \\
\hline $\mathrm{LSD}$ & 0.164 & 5.76 & 62.79 & 258.5 & 189.77 \\
\hline
\end{tabular}

Means followed by similar letters are not significantly different at $\mathrm{P} \leq 0.05$

\section{Conclusion and recommendation}

From these results it was concluded that quality and yield of wheat crop were significantly enhanced when zinc was supplied as a foliar spray at the lower rate of
$2.5 \mathrm{~kg} \mathrm{ha}^{-1}$ as compared to other methods. Foliar spray at the rate of $2.5 \mathrm{~kg} \mathrm{ha}^{-1}$ is recommended in zinc deficient soils to get better quality and yield of wheat crop. 


\section{Authors' contributions}

Conceived and designed the experiments: L Zada \& MJ Khan, Performed the Experiments: Rafiullah \& HU Rahim, Analyzed the Data: M Ali \& Samiullah, Contributed reagents/ materials/ analysis tools: IM Ahmad \& N Khan, Wrote the paper: S Ahmad \& Z Khan.

\section{Acknowledgment}

The authors are grateful to Prof. Dr Mohammad Jamal Khan and Assistant Prof Dr. Ishaq Mian Ahmad for their supervision and advice during this research experiment.

\section{References}

1. Government of Pakistan (2009). Pakistan Statistical Year Book-2006 Federal Bureau of Statistics, Statistics Division. Government of Pakistan pp. 23-24.

2. Ansari MA, Meman HR, Tunio SD \& Keerio SA (2006). Effect of planting pattern on growth and yield of wheat. Pakistan J Agri Agril Engg Vet Sc 22(2).

3. Marwat MI, Ahmad HK, Khan HH \& Khan A (2002). Integrated weed management in wheat. 1. Weed density, dry weed biomass, absolute growth rate and grain yield. Pakistan J Weed Sci Res 8(1-2): 81-93.

4. Chaudhary MA, Ali A, Siddique MA \& Sohail R (2000). Growth and yield response of wheat to different seed rates and wild oat (Avena fatua) competition durations. Pakistan J Agri Sci 37(3-4): 152-154.

5. MINFAL Agric (2009). Statistics of Pakistan. Ministry for Food, Agric \& Livest. Div (Econ. Wing) Govt of Pakistan, Islamabad Pakistan.

6. Tisdale SL, Nelson WL \& Beaten JD (1984). Zinc. In: Soil Fertility and Fertilizers, 4th edition pp: 382-391. Macmillan Publishing Company, New York, USA.

7. Potarzycki, J \& Grzebisz W (2009). Effect of zinc foliar application on grain yield of maize and its yielding components. Plant Soil Environ 55(12): 519-527.

8. Throne DW (1957). Zinc deficiency and its control. Adv Agron 9: 31-65.

9. Maqsood MA, Rahmatullah, Kanwal Aziz T \& Ashraf M (2009). Evaluation of $\mathrm{Zn}$ distribution among grain and straw of twelve indigenous wheat (Triticum Aestivum L.) genotypes. Pak J Bot 41(1): 225-231.

10. Anonymous (2004). National Nutrition Survey. 2001-2002. Planning Commission, Government of Pakistan, Islamabad, Pakistan.

11. Maralian H (2009). Effect of foliar application of $\mathrm{Zn}$ and $\mathrm{Fe}$ on wheat yield and quality. African J Biotechnol 8(24): 6795-6798.

12. Pahlavan RMR \& Pessarakli M (2009). Response of wheat plants to Zinc, Iron and manganese applications and uptake and concentration of zinc, iron and manganese in wheat grains. Commun. Soil Sci Plant Anal 40: 1322-1332.

13. Soltanpour PN \& Schwab AP (1977). A new soil test for simultaneous extraction of macro and micro nutrients in alkaline soils comm. Soil Sci Plant Anal 8: 195207.

14. Richard LA (1954). Diagnosis and improvement of saline and alkaline soils. Agri. Hand book-60 pp: 101-129.

15. Salimpour S, Khavazi K, Nadian H, Besharati H \& Miransari M (2010). Enhancing phosphorous availability to canola (Brassica napusL.) using $\mathrm{P}$ solubilizing and sulfur oxidizing bacteria, Australian Journal of Crop Science 4(5): 330-334.

16. Khorgamy A \& Farnia A (2009). Effect of phosphorus and zinc fertilization on yield and yield Components of chick pea cultivars. African Crop Science Conference Proceedings 9: 205-208.

17. Das K, Dang R, Shivananda TN \& Sur P (2005). Interaction between phosphorus 
and zinc on the biomass yield and yield attributes of the medicinal plant Stevia (Stevia Rebaudiana). Science World Journal 5: 390-395.

18. Marschner H, Oberle H Cakmak L \& Romheld V (1990). Growth enhancement by silicon in Cucumber (cucumis sativus) plants depends on imbalance in phosphorus and zinc supply. Plant and Soil 124: 211-219.

19. Sharma K, Krants BA, Brown AL \& Quick S (1986). Interaction of $\mathrm{Zn}$ and $\mathrm{P}$ in top and root of Corn and tomato. Agronomy Journal 60: 453-456.

20. Webb MJ \& Loneagan JF (1988). Effect of zinc deficiency on growth, phosphorus concentration and phosphorus toxicity of wheat plants. Soil Science Society of America 52: 16761680.

21. Hu D, Bell RW \& Xie Z (1996). Zinc and phosphor responses in transplanted oilseed rape. Soil Science and Plant Nutrient 42: 333-344.

22. Bukvicl G, Antunovic M, Popovic S \& Rastija M (2003). Effect of $P$ and $Z n$ fertilization on Biomass yield and its uptake by maize lines (Zea mays L.) Plant Soil Environ 49(11): 505-510.

23. Katya JC \& Randhawa NS (1983). Micronutrients FAO Fertilizer and Plant Nutrition Bullet In 7.Rome: Food and Agriculture Organization of the United Nations.
24. Shukla UC \& Moris HD (1967). Relative efficiency of several zinc sources for corn. Agron J 59: 200.

25. Viets FG (1966). Zinc Deficiency in Soil Plant System. In Prasad AS, Charles C \&Thomas Spring field II (Ed). Zinc Metabolism.

26. Rajput AL, Singh DP \& Singh SP (1995). Effect of soil and foliar application of nitrogen and zinc with farmyard manure on late sown wheat (Triticim aestivum L.). Indian J Agron 40(4): 598-600.

27. Torun A, Ltekin IGA, Kalayci M, Yilmaz A, Eker S \& Cakmak I (2001). Effects of zinc fertilization on grain yield and shoot concentrations of zinc, boron, and phosphorus of 25 wheat cultivars grown on a zinc-deficient and boron-toxic soil. J Plant Nutr 24(11): 1817 - 1829.

28. Zorita MD, Canigia MVF \& Grosso GA (2001). Applications of Foliar Fertilizers Containing Glycine butane Improve Wheat Yields. J Agron Crop Sci 186: 209.

29. Grewal, HS, Zhonggu L \& Graham RD (1997). Influence of subsoil zinc on dry matter production, seed yield and distribution of zinc in oilseed rape genotypes differing in zinc efficiency. Plant and Soil 192(2): 181-189. 